\title{
The rise and fall of glottalization in Baltic and Slavic
}

\author{
FREDERIK KORTLANDT \\ Rijksuniversiteit Leiden
}

\begin{abstract}
Glottalization is ancient in Balto-Slavic and was lost in Aukštaitian and Slavic at a comparatively recent stage. The Balto-Slavic acute directly reflects the PIE laryngeals and the glottalic feature of the PIE "unaspirated voiced" stops. It was a glottal stop which developed into a broken tone that was preserved under the stress in Žemaitian and outside the stressed syllable in Latvian. Tonal distinctions arose from a retraction of the stress and glottalization was lost under the new rising and falling tone movements. Consensus about the origins of the Baltic and Slavic tonal systems can only be reached if we give the data their proper due and do not let ourselves be diverted by unwarranted theoretical preconceptions.
\end{abstract}

According to the traditional doctrine, the Balto-Slavic acute and circumflex tones were rising and falling, respectively, in accordance with the Slavic, Prussian, and Latvian evidence, and changed places in Lithuanian, where the acute became falling and the circumflex rising (e.g., Stang 1957, 20 and 1966, 125). In Žemaitian, the acute tone developed into glottalization, which is usually called "broken tone" in Baltic linguistics, and the circumflex can be anything from rising in the east to falling in the west. In Latvian, the acute is reflected as a broken tone (i.e. glottalization) in originally mobile paradigms, allegedly as a result of the retraction of the stress to the initial syllable in this language. If this account of the facts is correct, glottalization (the "broken tone") developed independently in Žemaitian (under the stress) and Latvian (in originally pretonic syllables) and never arose in the other Balto-Slavic languages.

There are a number of reasons to call this account into question. First of all, it is highly improbable that glottalization developed independently in Žemaitian and Latvian, which are contiguous and structurally similar varieties of East Baltic. Secondly, both the motivation for and the mechanism of the Lithuanian change remain unexplained. Thirdly, the Žemaitian new rising and "middle" tones are not even mentioned. Fourthly, the interchange between rising and falling tone movements in derived forms, which is traditionally known as "metatony", is left out of consideration. Fifthly, the distribution of short and long reflexes of original long vowels in Slavic remains to be clarified. A reconsideration of these problems has led me to the conclusion that glottalization is ancient in Balto-Slavic and was lost in 
Aukštaitian and Slavic at a comparatively recent stage (cf. 1975, 1977, 1978b, 1983, 1985a, 1988a).

The possibility of an earlier broken tone in Balto-Slavic was first proposed by Vaillant, who suggested that the PIE laryngeals developed into a glottal stop which lengthened a preceding vowel or diphthong, yielding "une montée brusque de la voix" (1950, 244; cf. already 1936, 114). As a result of the rising tone movement, the new long vowels and diphthongs merged with the PIE lengthened grade vowels and diphthongs, which also had a rising tone movement, both in Greek and in Baito-Slavic. Vaillant leaves no doubt about his view that the acute of Gr. patếr 'father' and kheimôn 'winter' is older than the circumflex of Lith. duktẽ்; 'daughter' and akmuó 'stone' and that the broken tone of Latvian is due to a recent innovation $(1950,245,257)$. It follows that Vaillant's theory has no consequences for the interpretation of the Baltic and Slavic accentual data (cf. already Aitzetmüller 1962, 50).

On the basis of a direct comparison with Hittite, Mel'ničuk argued that the Latvian broken tone is the phonetic reflex of a PIE laryngeal (1960, 7-9). Since he discussed neither the rest of the Baltic and Slavic accentual data nor the fate of the PIE lengthened grade, his proposal remains a shot in the dark and seems to have been universally ignored. The case for a PIE origin of the Latvian and Žemaitian broken tones is in fact much stronger, as I have tried to show on a number of occasions (see especially Kortlandt 1977 and 1985a). As the problem is a highly complex one, the relevance of the pertinent data has taken a long time to be recognized in the scholarly community. It may therefore be useful to specify the basic differences between my views and some of those found in the recent literature on the subject.

In my view, the Balto-Slavic acute directly refiects the PIE laryngeals and the glottalic feature of the PIE "unaspirated voiced" stops (cf. Kortlandt $1985 \mathrm{~b}$ and 1988b). It was evidently a glottal stop which developed into a broken tone that was preserved under the stress in Žemaitian and outside the stressed syllable in Latvian (where it developed into a falling tone in area 3 and into a rising tone in area 7 of Andronov 1996). In Slavic, it was lost with compensatory lengthening in pretonic and post-positonic syllables and without compensatory lengthening under the stress and in the first posttonic syllable. Tonal distinctions arose from a retraction of the stress, both in East Baltic (cf. Kortlandt 1977, 324-328) and in Slavic (Kortlandt 1975, 28). Glottalization was lost under the new rising and falling tone movements. For a lucid introduction to the history of Baltic accentuation I refer to Derksen (1991).

My thesis that the Latvian broken tone continues a Balto-Slavic glottal stop has now been accepted by Young (1994, cf. Derksen 1995). Apart from the problem of metatony, which has been treated in detail by Derksen (1996), Young's account differs from mine in two major respects. First of all, he follows Garde's view (1976) that barytone case forms of mobile noun para- 
digms were inherently unstressed, so that the Latvian broken tone in original mobile paradigms is phonetically regular. $\mathrm{He}$ is evidently unaware of the fundamental difficulties which are inherent in this approach. As I have discussed these difficulties in detail elsewhere (1978a, 72-76), there is no reason to take the matter up again here. In addition, he disregards the chronological problem of the rise of unstressed nouns (cf. Kortlandt 1975, 9-10, 28, and 1977, 326).

Secondly, Young proposes that a stressed broken tone loses its glottalic feature by dissimilation before a following broken tone. This is the converse of Hjelmslev's view (1932) that every stressed syllable adopted the tone of the following syllable. Unlike Hjelmslev, Young does not discuss the counter-evidence, which is in both cases prohibitive. In order to contain the damage, he assumes that all stressed broken tones subsequently lost their glottalic feature by analogy. This is in effect a phonetic development which renders the previous glottalic dissimilation immaterial, so nothing is gained by his proposals. Young's article is an illustration of the fact that priority must be given to an analysis of the data, not to speculation about mechanisms of change.

The most recent treatment of the Balto-Slavic tones which has come to my attention is by Poljakov (1996), who evidently never had a look at any of my publications. This author thinks that Aukštaitian has preserved the original Balto-Slavic tones and that Žemaitian, Latvian, Prussian and Slavic all innovated in independent ways. He claims that "der Stoßton nur auf eine fallende Intonation zurückgehen kann" $(1996,168)$ and returns to the traditional view that it originated from a retraction of the stress, both in Latvian and in Žemaitian. His view is disproved in the same issue of the same journal by Andronov (1996), who shows that the broken tone yielded a falling tone in a part of the West Latvian dialects (area 3) and a new rising tone in a part of the East Latvian dialects (area 7). Poljakov does not discuss metatony and dismisses the Prussian and Slavic evidence as unclear and therefore secondary, without bothering about what has been written on the relevant issues in the course of the last four decades. While Stang sticks to the comparative method and looks for those forms "which together appear to provide the best basis of explanation for the largest number of forms in the separate languages" (1957, 3), Poljakov sneers at this data-oriented approach and prefers to start from general considerations, such as his axiom that the broken tone cannot be old and must be derived from an earlier falling tone movement.

Consensus about the origins of the Baltic and Slavic tonal systems can only be reached if we give the data their proper due and do not let ourselves be diverted by unwarranted theoretical preconceptions. The true nature of the Balto-Slavic acute can only be established on the basis of the total evidence provided by the reflexes in the daughter languages, which I have specified 
elsewhere (1985a, 122-123). The rise of the East Baltic tonal systems cannot be clarified without a discussion of the metatonical relationships (cf. Derksen 1991, 1995, 1996). Moreover, earlier scholarship must be taken seriously. Most of the issues have been around for a long time and many problems have been solved in recent decades. We cannot hope for progress when earlier findings are simply disregarded.

Cobetstraat 24

Frederik Kortlandt

$\mathrm{N}-2313 \mathrm{KC}$ Leiden

[fkort@mail.dsl.nl]

\section{REFERENCES}

AITZETMUlLer, R. 1962. Das baltoslavische Akzent- und Intonationssystem: Grundzüge und Grundprobleme, dargestellt nach dem heutigen Stand der Forschung. Die Sprache 8.46-58.

Андронов, А. 1996. Некоторыс замечания о просодических явлениях в диалектах латышского языка и их представления на карте. Baltistica 31:2.201-212.

DERKSEN, R. 1991. An introduction to the history of Lithuanian accentuation, in: Studies in Slavic and General Linguistics 16: Studies in West Slavic and Baltic Linguistics, 45-84. 1995. On the origin of the Latvian tones. Linguistica Baltica 4.163-168.

1996. Metatony in Baltic. Amsterdam: Rodopi.

GARDE, P. 1976. Histoire de l'accentuation slave. Paris: Institut d'études slaves.

HJELMSLEV, L. 1932. Études baltiques. Copenhague: Levin \& Munksgaard.

KORTLANDT, F. 1975. Slavic accentuation: A study in relative chronology. Lisse: Peter de Ridder.

-1977. Historical laws of Baltic accentuation. Baltistica 13:2.319-330.

1978a. A history of Slavic accentuation: Review of Garde 1976. Lingua 44:1.67-91.

-1978b. On the history of Slavic accentuation. Zeitschrift für vergleichende Sprachforschung 92:269-281.

-1983. Linguistic theory, universals, and Slavic accentuation. Folia Linguistica Historica $4: 1.27-43$.

1985a. Long vowels in Balto-Slavic. Baltistica 21:2.112-124.

1985b. Proto-Indo-European glottalic stops: The comparative evidence. Folia Linguistica Historica 6:2.183-201.

- 1988a. The laryngeal theory and Slavic accentuation, in: A. Bammesberger (ed.), Die Laryngaltheorie und die Rekonstruktion des indogermanischen Laut- und Formensysiems. Heidelberg: Carl Winter, 299-311.

- 1988b. Remarks on Winter's law. Studies in Slavic and General Linguistics 11: Dutch contributions to the 10th international congress of slavists: Linguistics, 387 - 396.

Мельничук, А. С. 1960. Следы взрьвного ларингального в ипдоевропейских язьпах. Вопросы языкознания 1960:3.3-16.

POLJAKOV, O. 1996. Zur Rekonstruktion der balto-slavischen Intonationen. Baltistica 31:2.163179.

STANG, C. S. 1957. Slavonic accentuation. Oslo: Universitetsforlaget.

—. 1966. Vergleichende Grammatik der Baltischen Sprachen. Oslo etc.: Universitetsforlaget.

VAILLANT, A. 1936. Le problème des intonations balto-slaves. Bulletin de la Société de Linguistique de Paris 37.109-115.

-1950. Grammaire comparée des langues slaves 1: Phonologie. Lyon-Paris: Éd. IAC.

YOUNG, S. R. 1994. Endzelin's law and acute tone in Latvian. Linguistica Baltica 3.101-108. 